\title{
Experimental studies on the performance and emission characteristics of a compression ignition engine fuelled with jatropha oil methyl ester
}

\author{
K. Bhaskar ${ }^{1}$, S. Sendilvelan ${ }^{2 *}$ \\ ${ }^{1}$ Department Automobile Engineering, Rajalakshmi Engineering College, Thandalam, \\ Chennai- 602 105, India. Email: kbhaskar66@yahoo.co.in \\ ${ }^{2}$ Department of Mechanical Engineering, Dr. M.G.R Educational and Research Institute, \\ Chennai-600 095, India, "Email:sendilvelan.mech@drmgrdu.ac.in
}

\begin{abstract}
In this work, biodiesel obtained from jatropha seedsare used as alternative fuel to diesel in stationary diesel engines. The oil obtained from the jatropha seeds are trans-esterified to get biodiesel. The biodiesel obtained has good ignition ability due to its relatively high cetane number compared to that of conventional diesel fuel. The oxygen component in the biodiesel fuel has the effect of reducing the pollutant concentration in exhaust gases due to better burning of the fuel in the engine. But the viscosity of biodiesel is very high compared to diesel and this affects its atomization and penetration characteristics and hence it is blended with diesel while being used as an alternate fuel in diesel engines. Performance and emission tests of Jatropha Oil Methyl Ester (JOME) and their blends $(80 \%, 60 \%, 40 \%, 20 \%)$ with diesel were carried out on a direct injection compression ignition engine at constant speed and at variable load conditions. The experimental results show that all the blends can be used as fuels for diesel engine without any major modification in the engines. It is also seen that the carbon monoxide, unburnt hydrocarbon and soot emissions are less at all loads for the blends compared to diesel fuel while oxides of nitrogen emissions are slightly higher. Tradeoff between oxides of nitrogen and soot emissions for various percentage of JOME in blends show that $19 \%$ of JOME blend are observed to be optimum considering both NOx and soot emissions. At the rated power output $(4.4 \mathrm{~kW})$ the $\mathrm{NO}_{\mathrm{x}}$ emissions are $7.46 \mathrm{~g} / \mathrm{kWh}$ and the soot emissions are $120 \mathrm{mg} / \mathrm{m}^{3}$ for $19 \%$ JOME compared with diesel the $\mathrm{NO}_{\mathrm{x}}$ emissions are $7.25 \mathrm{~g} / \mathrm{kWh}$ and the soot emissions are $166 \mathrm{mg} / \mathrm{m}^{3}$.
\end{abstract}

Keywords: Biodiesel;jatrophaoil methyl ester;emission analysis;compression ignition engine;optimum blend.

\section{INTRODUCTION}

The energy requirements are more and at the same time the resources depleting very fast. The crisesare caused due to huge dependence on non-renewable energy resources fossil fuels[1]. If the fossil fuel production remains constant, it is estimated that the reserves will be depleted soon. Due to the running down of the petroleum reserves and the growing environmental concerns, there is an extensive demand for non-conventional sources of energy [2]. Augmented regulations for particulate matter and NOx, and also the issues raised on the emission of greenhouse gases like $\mathrm{CO}_{2}$ are the reasons for biofuels being subjected to demanding research work all over the world[3]. Biodiesel 
derived from the transesterification of fats and oils is a possible fuel for diesel engines[4]. Properties of this fuel is comparable to that of diesel and can be used directly to run the existing diesel engines or as a blend with crude oil diesel [5]. Biodiesel is renewable, biodegradable and non-toxic[6]. With diesel it increases fuel lubricity and operates in compression ignition engines with little or no modification [7]. Furthermore, biodiesel offers compensations regarding engine wear, cost and availability[8][9]. Pollutants produced are less harmful than fossil fuels[10]. Biodiesel has lesser sulphur content, lesser aromatic content and oxygen containing compounds due to which the emissions of $\mathrm{SO}_{2}, \mathrm{CO}_{2}, \mathrm{HC}$ and $\mathrm{PM}$ are reduced. Besides, it has good ignition ability in engine owing to its high cetane number compared to that of conventional diesel fuel [11].

The transesterification process is based on the chemical reaction of a triglyceride with an alcohol in the presence of a catalyst potassium hydroxide, producing biodiesel and glycerin[12].Castor, palm, sunflower, pea nut and soybean oils can be used as biodiesel sources(Valente, Da Silva, Pasa, Belchior, \& Sodre, 2010), but all these are used for cooking purposes. Hence, instead of using edible oils for the production of biodiesel, non-edible oils can be used for the same. Low cost [14] renewable raw material is a very important requirement for economic production of biodiesel.

Among the vegetable oils, jatropha oil has very good properties. It is non-edible oil, its calorific value and cetane number are higher compared to many others. The jatropha can grow anywhere, suitable for all conditions. Based on the studies available it is the best substitute available at present to fossil fuel[15]. This paper presents experimental results of 100\% JOME and 80\%, 60\%, 40\% and also 20\% JOME blends with diesel on the performance and emission characteristics of the engine. This work brings out the possibility of partial replacement of diesel to reduce the dependence of petroleum-based diesel fuel.

\section{PROPERTIES OF METHYL ESTERS}

Most modern diesel engines have direct injection fuel systems which are more sensitive to fuel spray quality than indirect injection engines and they require a fuel with properties that are closer to diesel fuel. Table 1 shows the fuel properties of JOME and Diesel fuel. The composition of fatty acids present in JOME as provided by the suppliers is given in Table 2. There is no long-chain hydrocarbons ranging from C:20 to $\mathrm{C}: 22$ in JOME. It is also observed that $25.6 \%$ of JOME comprises of saturated fatty acid methyl esters.

Table 1. Fuel Properties of Biodiesel from JOMEand Diesel fuel

\begin{tabular}{lccccc}
\hline \multicolumn{1}{c}{ Fuel Property } & Unit & Source & Diesel & $\begin{array}{c}\text { Limits as per } \\
\text { IS 15607-2005 }\end{array}$ & JOME \\
& & & & ASTM D6751 & \\
\hline $\begin{array}{l}\text { Density at } 15^{\circ} \mathrm{C} \\
\text { Kinematic }\end{array}$ & $\mathrm{kg} / \mathrm{m}^{3}$ & Measured & 830 & $860-900$ & 882 \\
Viscosity at $40^{\circ} \mathrm{C}$ & $\mathrm{cSt}$ & Measured & 3.52 & $1.9-6.0$ & 4.5 \\
$\begin{array}{l}\text { Flash Point } \\
\text { Calculated Cetane }\end{array}$ & ${ }^{\circ} \mathrm{C}$ & Measured & 54 & 120 min & 160 \\
Index & - & Measured & 50 & - & 54 \\
\hline
\end{tabular}




\begin{tabular}{lccccc}
\hline Calorific Value & MJ/kg & Measured & 43.5 & - & 39.64 \\
Element O & wt. \% & $\begin{array}{c}\text { Given by } \\
\text { Supplier }\end{array}$ & - & - & 10.8 \\
\hline
\end{tabular}

Table 2. Comparison of the Fatty Acid Composition (wt \%) of Jatropha Oil Methyl Esters (JOME)

\begin{tabular}{lccr}
\hline Types of Fatty Acids & $\begin{array}{c}\text { Chemical } \\
\text { Structure }\end{array}$ & Type & JOME* \\
\hline Myristic Acid & C14:0 & S & 0.70 \\
Palmitic Acid & C16:0 & S & 15.30 \\
Palmitoleic Acid & $\mathrm{C} 16: 1$ & US & - \\
Heptadecanoic Acid & $\mathrm{C} 17: 0$ & $\mathrm{~S}$ & - \\
Stearic Acid & $\mathrm{C} 18: 0$ & $\mathrm{~S}$ & 9.60 \\
Oleic Acid & $\mathrm{C} 18: 1$ & $\mathrm{US}$ & 40.60 \\
Linoleic Acid & $\mathrm{C} 18: 2$ & $\mathrm{US}$ & 33.40 \\
Linolenic Acid & $\mathrm{C} 18: 3$ & $\mathrm{US}$ & 0.30 \\
Arachidic Acid & $\mathrm{C} 20: 0$ & $\mathrm{~S}$ & - \\
Eicosadienoic Acid & $\mathrm{C} 20: 2$ & $\mathrm{US}$ & - \\
Eicostetraenoic Acid & $\mathrm{C} 20: 4$ & $\mathrm{US}$ & - \\
Eicospentaenoic Acid & $\mathrm{C} 20: 5$ & $\mathrm{US}$ & - \\
Behenic Acid & $\mathrm{C} 22: 0$ & $\mathrm{~S}$ & - \\
Docosapentaenoic Acid & $\mathrm{C} 22: 5$ & $\mathrm{US}$ & - \\
Docosahexa-Enoic Acid & $\mathrm{C} 22: 6$ & $\mathrm{US}$ & - \\
Saturated Fatty Acids (S) & $\mathrm{C} 14-\mathrm{C} 18$ & & 25.60 \\
Unsaturated Fatty Acids (US) & $\mathrm{C} 18: 1,2,3$ & & 74.30 \\
Long Carbon-chain Fatty Acid & $\mathrm{C} 20-\mathrm{C} 22$ & & - \\
$\quad$ (*provided by the supplier) & & & \\
\hline
\end{tabular}

Since biodiesel has different physical and chemical properties compared to petroleum-based diesel fuel, it will affect the engine performance and emission when used without engine modification. All the properties of biodiesel meet ASTM D 675102 specifications[16]. JOME contain $10.8 \%$ of oxygen by weight and have higher cetane numbers compared to Diesel[17]. Viscosity is an important property that affects flow and atomization characteristics of liquid fuel. In general, kinematic viscosity increases with increase in saturated longer chain fatty acids[18]. From Table 1, it can be observed that JOME have higher kinematic viscosity than diesel. Its viscosity and specific gravity are higher than those of diesel and hence fuel quantity, injection timing, and spray pattern of biodiesel are different from those of diesel[19]. Compared to diesel, methyl esters of jatropha oil have poor injection and atomization characteristics, but offer better lubrication and protection for fuel injection equipments[19].

Heating value is an important property of fuel which determines the amount of power generated per unit of fuel consumed. Heating values of JOME and Diesel are $39.64 \mathrm{MJ} / \mathrm{kg}$ and $43.5 \mathrm{MJ} / \mathrm{kg}$ respectively[20]. As the higher heating value of JOME are about $8.87 \%$ less than that of diesel it causes some power loss and the amount of fuel to be injected into the combustion chamber is also higher to produce the same power. Due to the presence of oxygen content in JOME, carbon and hydrogen 
percentages are lower in them compared to diesel and the reduced hydrocarbon content leads to its lower heating value compared to diesel[21].

Cetane number is a good indicator of quality of fuel for use in C.I. engines. Higher cetane number reduces ignition delay[22]. Cetane number depends upon the molecular structure. Fuels with longer straight-chain hydrocarbons have higher cetane number. The presence of branched chain structure reduces the cetane number[22]. A related parameter, Cetane index, is calculated from fuel density and distillation test[23]. Cetane index provides a reasonably close approximation to cetane number. The higher the cetane index, higher is the cetane number[24]. As observed from Table 1 calculated Cetane index for JOME is higher compared to diesel fuel. The higher cetane number of biodiesel results in a shorter ignition delay and advances the combustion timing. The ignition delay, which is the time between the start of injection and the start of combustion, will be affected when the injection timing or the start of injection is varied[25].

\section{EXPERIMENTAL SETUP}

The tests are conducted on a single cylinder, four stroke, naturally aspirated, air-cooled diesel engine coupled with an electrical swinging field dynamometer. The detailed technical specifications of the engine are given in Table 3. Figure 1 shows the schematic diagram of the experimental set-up. The intake manifold of the engine is modified to fit the primary fuel injector. Fuel was pressurized from 0-6 bar using an electronic fuel pump and injected into the intake manifold using a Multi-Point Fuel Injection (MPFI) fuel injector. AVL 415 Variable Sampling Smoke meter is used to measure the particulate matter in the exhaust. MRU delta 1600 L Exhaust Gas Analyzer is used to measure $\mathrm{HC}, \mathrm{CO}$ and NOx emissions. AVL 615 Indimeter system is used to get pressure crank angle diagram at various loads using piezoelectric pressure transducer and angle encoder and to process the same for getting various parameters such as heat release rate curve, peak pressure, angle of occurrence of peak pressure, imep,.

Table 3. Test Engine Specifications

\begin{tabular}{ll}
\hline Item & Description \\
\hline Make and Model & $:$ Kirloskar, TAF1 make \\
General Details & $:$ Four stroke, compression ignition, constant \\
& $:$ speed, vertical, air cooled, direct injection \\
Number of Cylinders & $: 87.5 \mathrm{~mm}$ \\
Bore & $: 110 \mathrm{~mm}$ \\
Stroke & $: 661 \mathrm{cc}$ \\
Swept Volume & $: 36.87 \mathrm{cc}$ \\
Clearance Volume & $: 17.5: 1$ \\
Compression Ratio & $: 4.4 \mathrm{~kW}$ at $1500 \mathrm{rpm}$ \\
Rated Output & $: 1500 \mathrm{rpm}$ \\
Rated Speed & $:$ Mechanical \\
Type of Injection Pump & $: 3$ holes \\
Nozzle Holes & $: 0.25 \mathrm{~mm}$ \\
Spray Hole Diameter & $: 200 \mathrm{bar}$ \\
Nozzle Opening Pressure & $: 110^{\circ}$ \\
Cone Angle & $:$ Mechanical \\
Type of Injector &
\end{tabular}




\begin{tabular}{ll}
\hline Needle Lift & $: 0.25 \mathrm{~mm}$ \\
Fuel Injection Timing & $: 23{ }^{\circ} \mathrm{CA}$ bTDC \\
Fuel Injection Duration & $: 20-30{ }^{\circ} \mathrm{CA}$ \\
Type of Combustion Chamber & $:$ Hemispherical Open Combustion Chamber \\
& $\begin{array}{l}\text { without offset with } 52 \mathrm{~mm} \text { diameter on top. } \\
\end{array}$ \\
& Bowl volume is approximately $40 \mathrm{~cm}^{3}$ \\
Valve Timing & $: 4.5^{\circ} \mathrm{CAbTDC}$ \\
Intake Valve Opening & $: 35.5^{\circ} \mathrm{CA}$ aBDC \\
Intake Valve Closing & $: 35.5^{\circ} \mathrm{CAbBDC}$ \\
Exhaust Valve Opening & $: 4.5^{\circ} \mathrm{CA}$ aTDC \\
Exhaust Valve Closing &
\end{tabular}

\section{Experimental Procedure}

The engine is started with diesel and allowed to warm up till steady state conditions are achieved. Engine speed, fuel consumption rate, exhaust emissions $\left(\mathrm{HC}, \mathrm{CO}\right.$, and $\mathrm{NO}_{\mathrm{X}}$ ), smoke intensity, pressure-crank angle diagram and exhaust gas temperature are measured at various loads. The experiment is repeated at various loads with JOME fuel and also various percentages of JOME blends with diesel. Experiments were conducted with 20\%, 40\%, 60\%, 80\% JOME blends with diesel and 100\% JOME.Errors and uncertainties in the experiment are important to determine the accuracy of the results obtained. So, instruments/analyzers were selected carefully and the percentage uncertainties of various parameters are given in Table 4.Experiments were conducted for 25 set of readings to evaluate the uncertainty of any measured parameter (x) with same operating conditions. From the measured parameter, the mean value (xm) and standard deviation $(\sigma)$ were obtained and uncertainty is calculated using the following equations:

$$
\text { Uncertainty of measured quantity }=\Delta x=(2 \sigma / x m) * 100
$$

The Uncertainties in the calculated parameters (function of measured independent parameters) are evaluated by using the expression

$$
\Delta \text { he Uncsqrt }\left[(\Delta \mathrm{x} / \mathrm{x})^{2}+(\Delta \mathrm{y} / \mathrm{y})^{2}\right]
$$

\begin{tabular}{|c|c|c|c|c|}
\hline S.No & Instruments & Range & Accuracy & $\begin{array}{c}\text { Percentage } \\
\text { Uncertainties }\end{array}$ \\
\hline \multirow[t]{3}{*}{1} & Gas analyzer & $\mathrm{CO}: 0-10 \%$, & $\pm 0.01 \%$ vol. & \pm 0.5 \\
\hline & & HC : 0-20,000ppm, & $\pm 1 \mathrm{ppm}$ & \pm 5.0 \\
\hline & & $\mathrm{NO}_{\mathrm{x}}: 0-5,000 \mathrm{ppm}$ & $\pm 1 \mathrm{ppm}$ & \pm 10.0 \\
\hline \multirow{2}{*}{$\begin{array}{l}2 . \\
3 .\end{array}$} & Smoke Meter & $0-31,999 \mathrm{mg} / \mathrm{m}^{3}$ & $\pm 0.02 \mathrm{mg} / \mathrm{m}^{3}$ & \pm 5 \\
\hline & $\begin{array}{l}\text { Thermocouple } \\
\text { (K Type) }\end{array}$ & $0-1000{ }^{\circ} \mathrm{C}$ & $\pm{ }^{o} 1$ & \pm 0.15 \\
\hline 4. & $\begin{array}{l}\text { Speed Measuring } \\
\text { Unit }\end{array}$ & $0-9,999 \mathrm{rpm}$ & $\pm 10 \mathrm{rpm}$ & \pm 0.1 \\
\hline 5. & Load Indicator & $0-100 \mathrm{~kg}$ & $\pm 0.1 \mathrm{~kg}$ & \pm 0.2 \\
\hline 6. & Volumetric Fuel & $0-100 \mathrm{cc}$ & $\pm 0.1 \mathrm{cc}$ & \pm 1 \\
\hline
\end{tabular}

Table 4.List of Instruments and their Range, Accuracy, and Uncertainties 


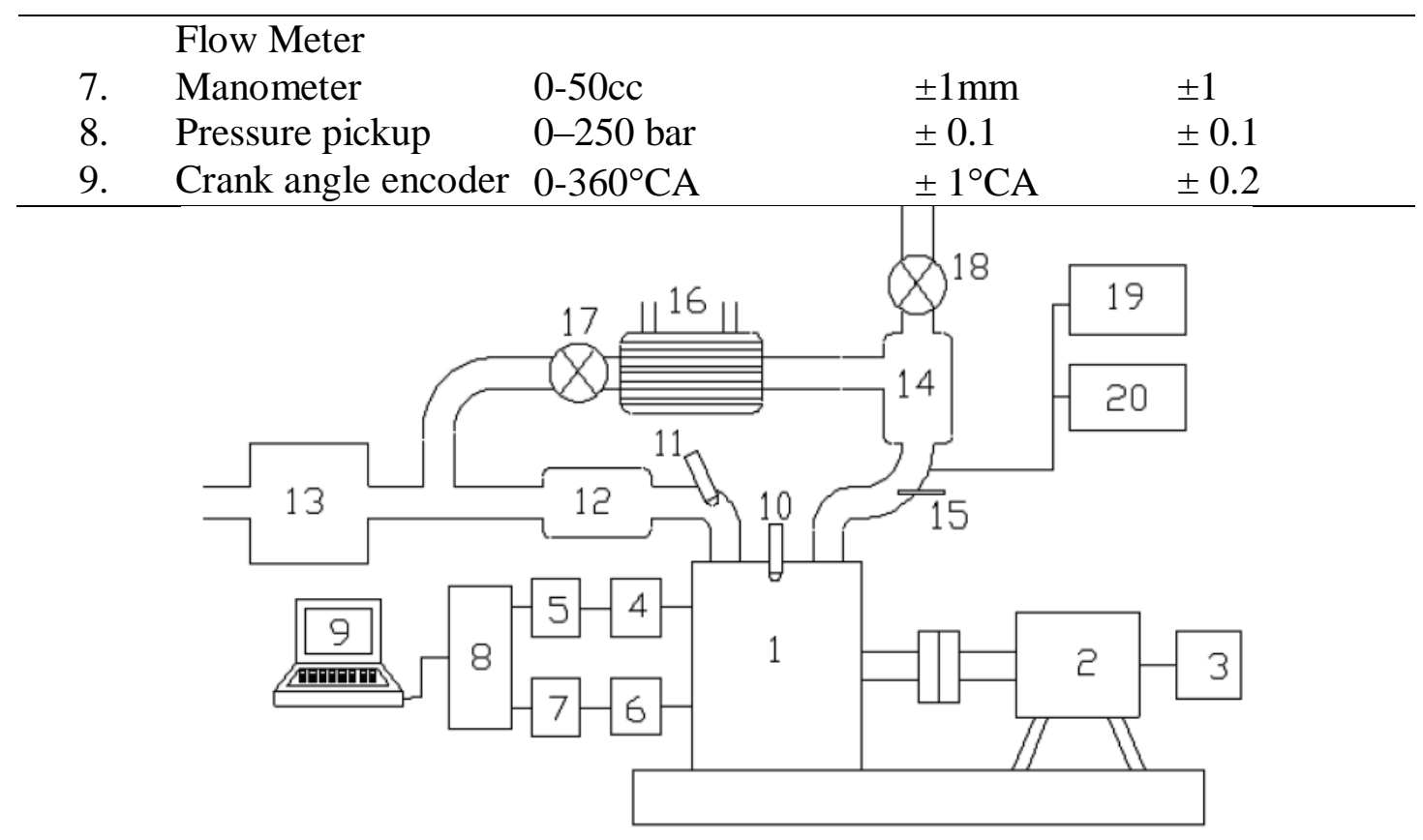

Figure 1. Experimental Setup

$\begin{array}{clrl}1 & \text { Diesel Engine } & 11 & \text { Premixed fuel injector } \\ 2 & \text { Electrical Dynamometer } & 12 & \text { Mixing chamber } \\ 3 & \text { Dynamometer Controls } & 13 & \text { Air flow measurement } \\ 4 & \text { Pressure pickup } & 14 & \text { Settling chamber } \\ 5 & \text { Charge amplifier } & 15 & \text { Thermocouple } \\ 6 & \text { TDC position sensor } & 16 & \text { EGR Cooler } \\ 7 & \text { TDC amplifier circuit } & 17 & \text { EGR Valve } \\ 8 & \text { A/D Card } & 18 & \text { Back pressure control valve } \\ 9 & \text { Personal computer } & 19 & \text { Exhaust gas analyzer } \\ 10 & \text { Main Injector } & 20 & \text { AVL smoke meter }\end{array}$

The following notations are used in this chapter:

- JOME and 100\% JOME - Jatropha oil methyl ester

- $\mathrm{xx} \% \mathrm{JOME}-\mathrm{xx}$ refers to the percentage of JOME in the blend of JOME and Diesel

\section{RESULTS AND DISCUSSION}

\section{Specific Energy Consumption (SEC) and Brake Thermal Efficiency (BTE)}

Figure 2 and 3 show the variation of specific energy consumption and brake thermal efficiency respectively with brake power for diesel, 20\%, 40\%, 60\%, 80\% JOME and JOME. Specific energy consumption and brake thermal efficiency are inversely proportional to each other. SEC is the input energy required to develop unit power output and by comparing methyl esters with diesel, methyl esters are showing comparatively higher values of SEC. 


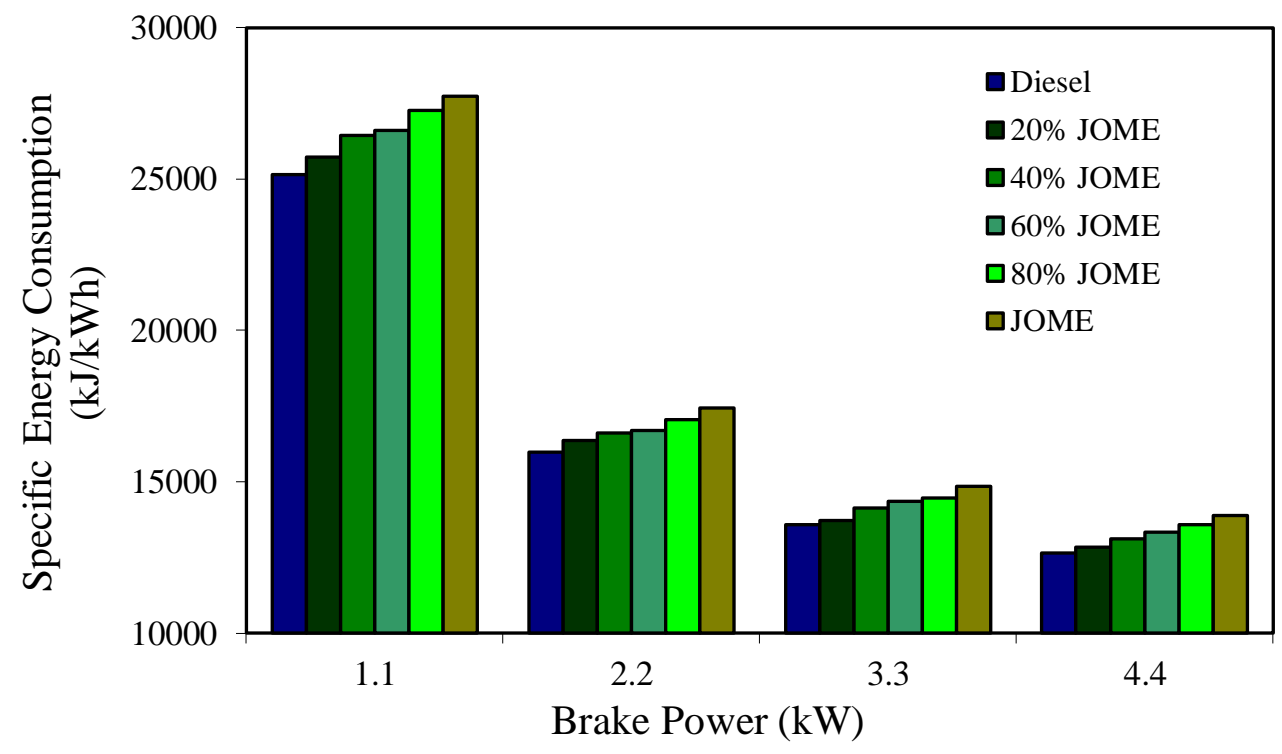

Figure 2. Variation of Specific Energy Consumption with Brake power

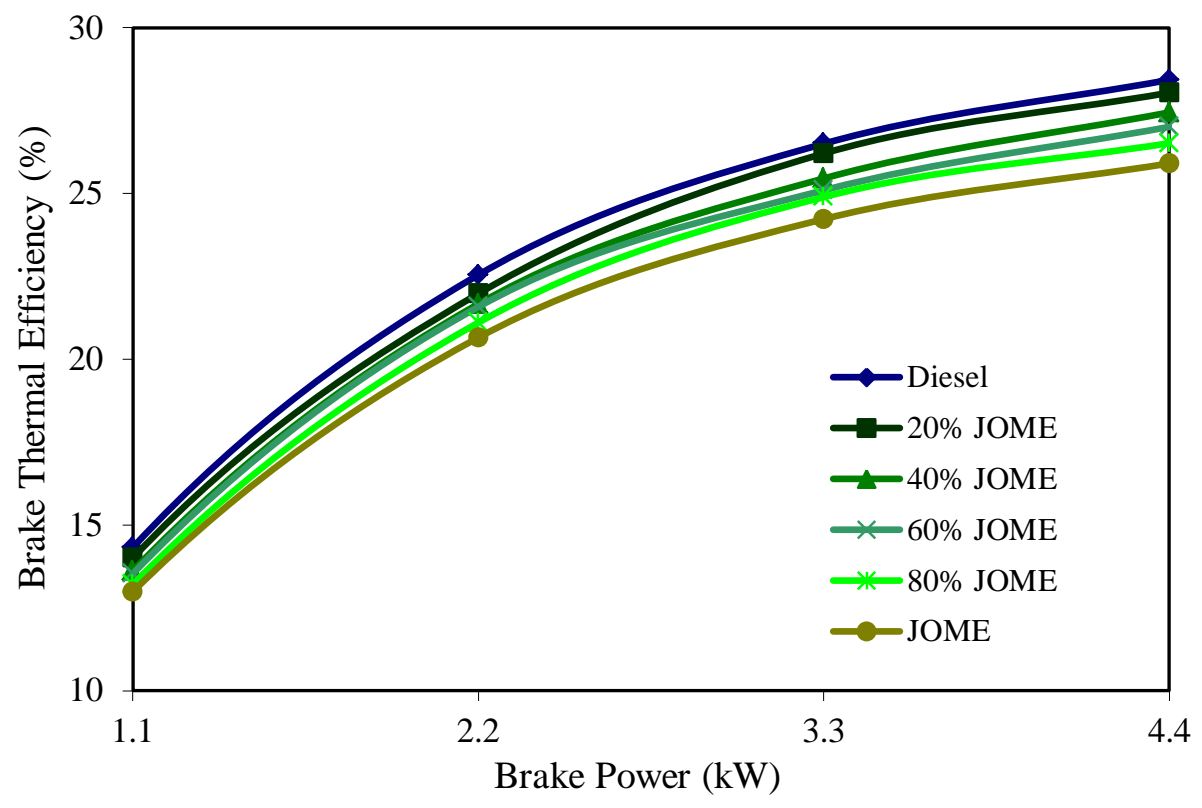

Figure 3. Variation of Brake Thermal Efficiency with Brake Power

SEC is higher and hence brake thermal efficiency is lower for the methyl ester and their blends at all power outputs compared to diesel. At rated power output (4.4 $\mathrm{kW}$ ) the Specific Energy Consumption of various fuels tested varies from 12,661.27 $\mathrm{kJ} / \mathrm{kWh}$ to $13,894.25 \mathrm{~kJ} / \mathrm{kWh}$ and the brake thermal efficiency varies from $28.43 \%$ to $25.91 \%$. Higher kinematic viscosities of JOME blends $(4.5 \mathrm{cSt})$ compared to that of diesel $(3.52 \mathrm{cSt})$ result in poor atomization, vaporization and dispersion of fuel in the combustion chamber. Lower calorific value of JOME blends $(39,640 \mathrm{~kJ} / \mathrm{kg})$ compared to diesel $(43,500 \mathrm{~kJ} / \mathrm{kg})$ result in higher fuel consumption of blends compared to diesel at all the power outputs resulting in higher SEC and lower brake thermal efficiency. 


\section{Exhaust Gas Temperature (EGT)}

The exhaust gas leaving the cylinder determines the extent of temperature reached during the combustion process. With increase in load, the temperature of the exhaust gases increases for all the fuels. It is also observed from the Figure 4, that the exhaust gas temperature increases with percentage of methyl ester in the fuel for all the loads.

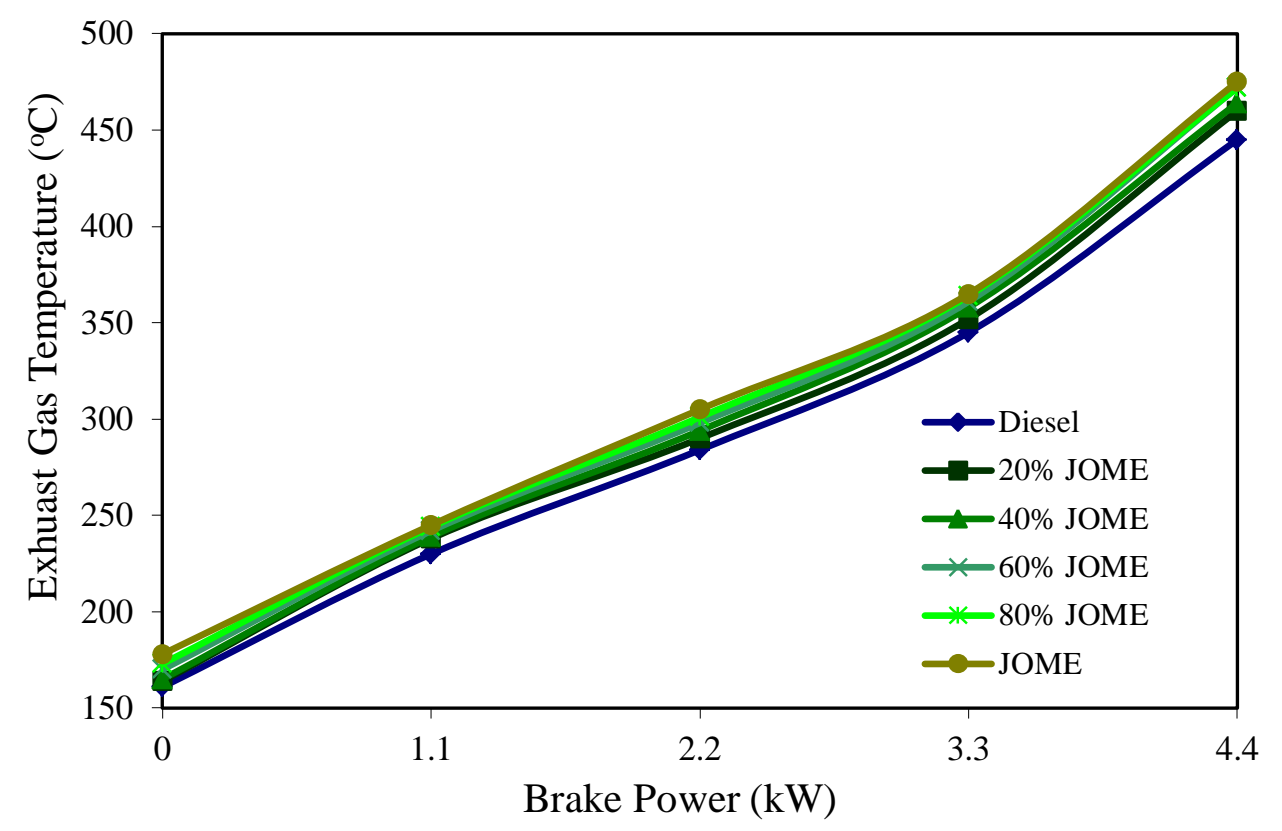

Figure 4. Variation of Exhaust Gas Temperature with Brake power

This may be due to the oxygen content of the methyl esters, which improves combustion.Intrinsic oxygen present in the fuel about $10.8 \%$ by wt. in JOME will help the combustion process. The oxygen in biodiesel finds it easy to participate in the combustion reaction. The addition of biodiesel to diesel provides more oxygen to the combustion reaction and promotes complete combustion. Also the poor fuel atomization and vaporization due to higher viscosity of the methyl esters and their blends results in late burning of injected fuel and results in higher exhaust gas temperature [26]. At rated power output $(4.4 \mathrm{~kW})$ the Exhaust Gas Temperature of various fuels tested varies from $475^{\circ} \mathrm{C}$ to $445^{\circ} \mathrm{C}$.

\section{Hydrocarbon Emissions (HC)}

Figure 5 shows that the variation of $\mathrm{HC}$ emissions with brake power. It can be seen that with increase in brake power, $\mathrm{HC}$ emissions increases for all the test fuels and there has been considerable reduction of HC emissions for JOME and JOME blends than diesel. A significant reduction in UBHC emissions is noticed for both the methyl esters and their blends at all the power outputs compared to diesel. 


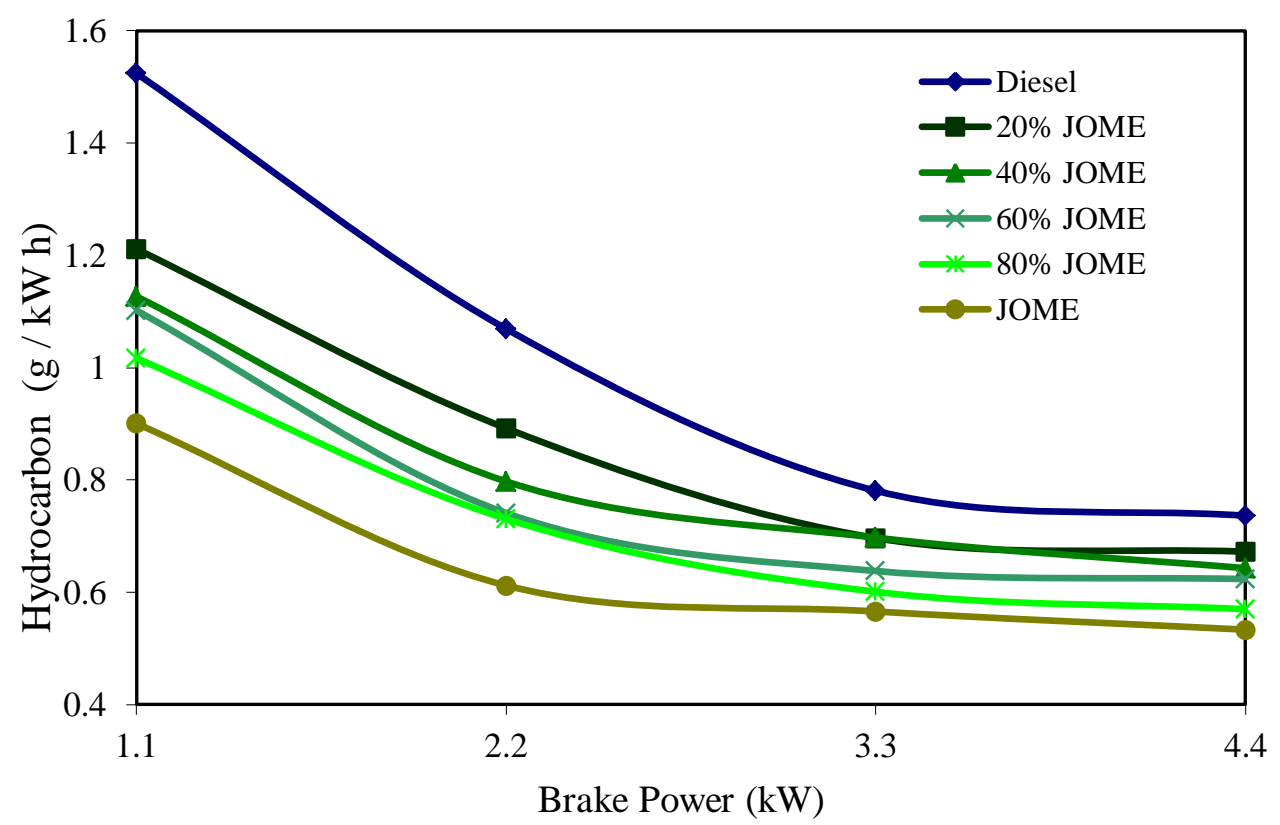

Figure 5. Variation of Unburnt Hydrocarbon with Brake Power

This may be due to their intrinsic oxygen content of JOME (10.8\% by wt.) whereas, diesel does not have oxygen[27]. The addition of methyl ester to diesel increases the oxygen content enhancing the combustion reactions resulting in high combustion temperature which lowers UBHC emissions [28]. The oxygen in biodiesel finds it easy to participate in the combustion reaction. The addition of biodiesel to diesel provides more oxygen to the combustion reaction and promotes complete combustion especially for those areas at the core of the fuel spray [29]. The oxygen surrounding the fuel droplets would take relatively larger time to assist the combustion of fuel droplet[30]. The reduction of UBHC in CI engines is also due to lower content of carbon to hydrogen ratio than the normal diesel due to the presence of oxygen in its molecular structure. With methyl esters having higher Cetane Index (CI) than diesel, delay period gets reduced and it leads to effective combustion which reduces HC emissions to a greater extent[31]. At rated power output $(4.4 \mathrm{~kW})$ the Unburnt Hydrocarbon of various fuels tested varies from $0.7366 \mathrm{~g} / \mathrm{kWh}$ to $0.534 \mathrm{~g} / \mathrm{kWh}$.

\section{Carbon Monoxide Emissions (CO)}

Figure 6 shows the variation of carbon monoxide emissions with brake power. With increase in brake power, $\mathrm{CO}$ emission increases for all the test fuels. $\mathrm{CO}$ emissions results due to lack of oxygen during combustion. In general, the $\mathrm{CO}$ emissions are low for diesel engines as they are operated with lean mixtures. With methyl esters where oxygen content is higher, it leads to efficient and effective combustion. Therefore, a CO emission reduces for all the blends comparatively. The methyl esters are having higher cetane index due to which combustion quality will be good which reduces the $\mathrm{CO}$ emissions considerably[32]. As the percentage of methyl ester in the blend increases it is observed that the $\mathrm{CO}$ emission decreases. The $\mathrm{CO}$ emission also depends upon the carbon to hydrogen ratio and in-cylinder temperature. 


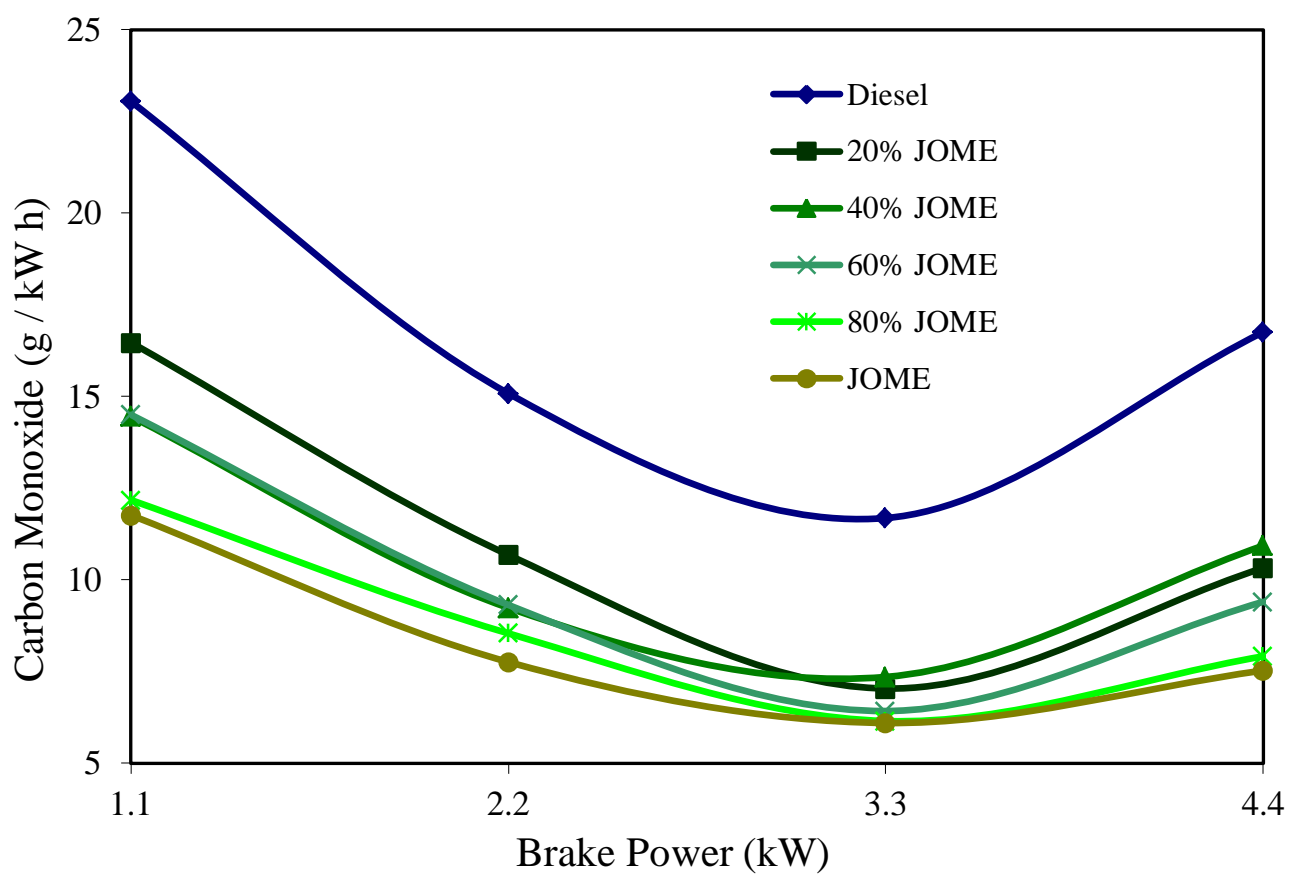

Figure 6. Variation of Carbon Monoxide with Brake Power

In the case of JOME and JOME blends, carbon to hydrogen ratio is comparatively lower and the in-cylinder temperature is higher compared to diesel. These factors reduce the formation of carbon monoxide [28]. It can be observed that $\mathrm{CO}$ decreases with increase in power output except at rated power for all the fuels tested. At rated power, the quantity of fuel injected is more while the quantity of air inhaled is constant and this may result in an increase in $\mathrm{CO}$ emission for all the fuels tested. At rated power output $(4.4 \mathrm{~kW})$ the Carbon-Monoxide emissions of various fuels tested varies from $16.75 \mathrm{~g} / \mathrm{kWh}$ to $7.53 \mathrm{~g} / \mathrm{kWh}$.

\section{NOx Emissions}

The variation of NOxemission with power output for various fuels tested is shown in Figure 7. Oxides of Nitrogen $\left(\mathrm{NO}_{\mathrm{x}}\right)$ consist of Nitric oxide (NO) and Nitrogen dioxide $\left(\mathrm{NO}_{2}\right)$. Nitric oxide is predominant in the oxides of nitrogen produced inside the engine cylinder. $\mathrm{NO}_{2} / \mathrm{NO}$ in a diesel engine is approximately in the ratio of 0.1 to 0.3 [33]. Oxides of Nitrogen emissions $\left(\mathrm{NO}_{\mathrm{x}}\right)$ emissions are higher for the methyl ester and its blend compared to diesel[34]. The exhaust gas temperatures are higher for JOME at all the power outputs compared to diesel. NO formation also occurs through the nitrogen present in the fuel. The fossil fuels do not contain nitrogen or very negligible amount of nitrogen. Hence, the amount of NO formed from the fuel is very low and it is observed that NO increases slowly with increasing temperature and increased NO levels can occur at increased flame temperatures. 


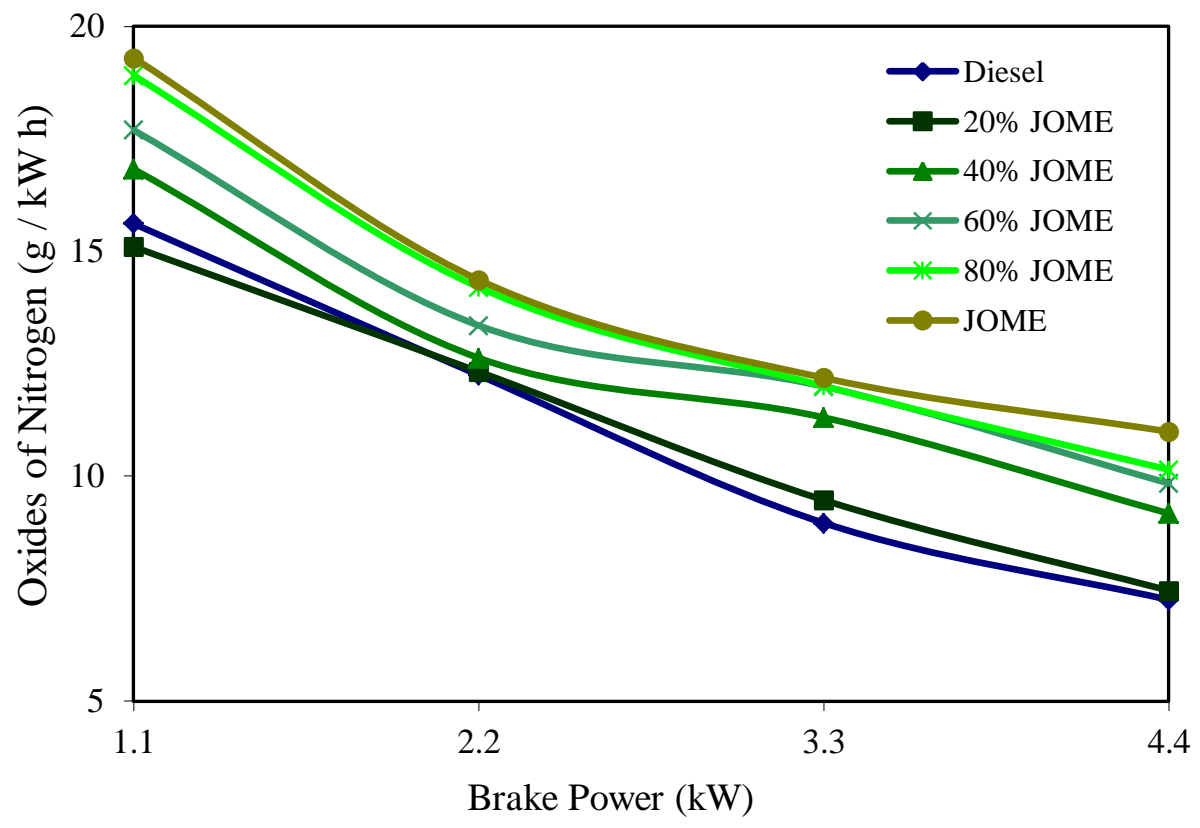

Figure 7. Variation of Oxides of Nitrogen with Brake power

For diesel, the NOx emissions vary from $15.6 \mathrm{~g} / \mathrm{kWh}$ at $20 \%$ of rated power output to $7.45 \mathrm{~g} / \mathrm{kWh}$ at rated power output. For $20 \% \mathrm{JOME}, 40 \% \mathrm{JOME}, 60 \% \mathrm{JOME}$, 80 JOME and JOME the variations are from 15.09 to $7.456 \mathrm{~g} / \mathrm{kWh}, 16.82$ to 9.17 $\mathrm{g} / \mathrm{kWh}, 17.7 \mathrm{~g} / \mathrm{kWh}$ to $9.84 \mathrm{~g} / \mathrm{kWh}, 18.9 \mathrm{~g} / \mathrm{kWh}$ to $9.84 \mathrm{~g} / \mathrm{kWh}$ and $19.29 \mathrm{~g} / \mathrm{kWh}$ to $10.98 \mathrm{~g} / \mathrm{kWh}$ respectively.

\section{Soot Emissions}

Figure 8 shows that soot emissions increases with brake power. It is observed that JOME in its blends areshowing lower value of soot compared to diesel due to their higher oxygen content and higher cetane index which improve the combustion process. At rated power output $(4.4 \mathrm{~kW})$ the Soot emissions of various fuels tested varies from $166 \mathrm{mg} / \mathrm{m}^{3}$ to $88 \mathrm{mg} / \mathrm{m}^{3}$.

Diesel particulate matter consists of highly agglomerated solid carbonaceous material (soot), ash, volatile organic and Sulphur compounds resulting from incomplete combustion of hydrocarbons present in fuel; it is also partly contributed by the burning of lubricating oil. Soot is formed in locally rich regions during combustion. Most of the soot formed is subsequently oxidized [35]. A small fraction of the evaporated fuel and lubricating oil does not undergo oxidation and appear as soluble organic fractions (SOF) in the exhaust [36]. The increase in soot emission for diesel fuel is also due to higher boiling point and thermal stability of aromatic hydrocarbons present in it. In particular, the presence of branched and ring (multi-ring or poly) structure of diesel fuel can increase the soot levels [37]. Higher boiling point paraffin or aromatics adsorbed from particulates emitted by the engine are reported to increase volatile organic fractions [36]. 


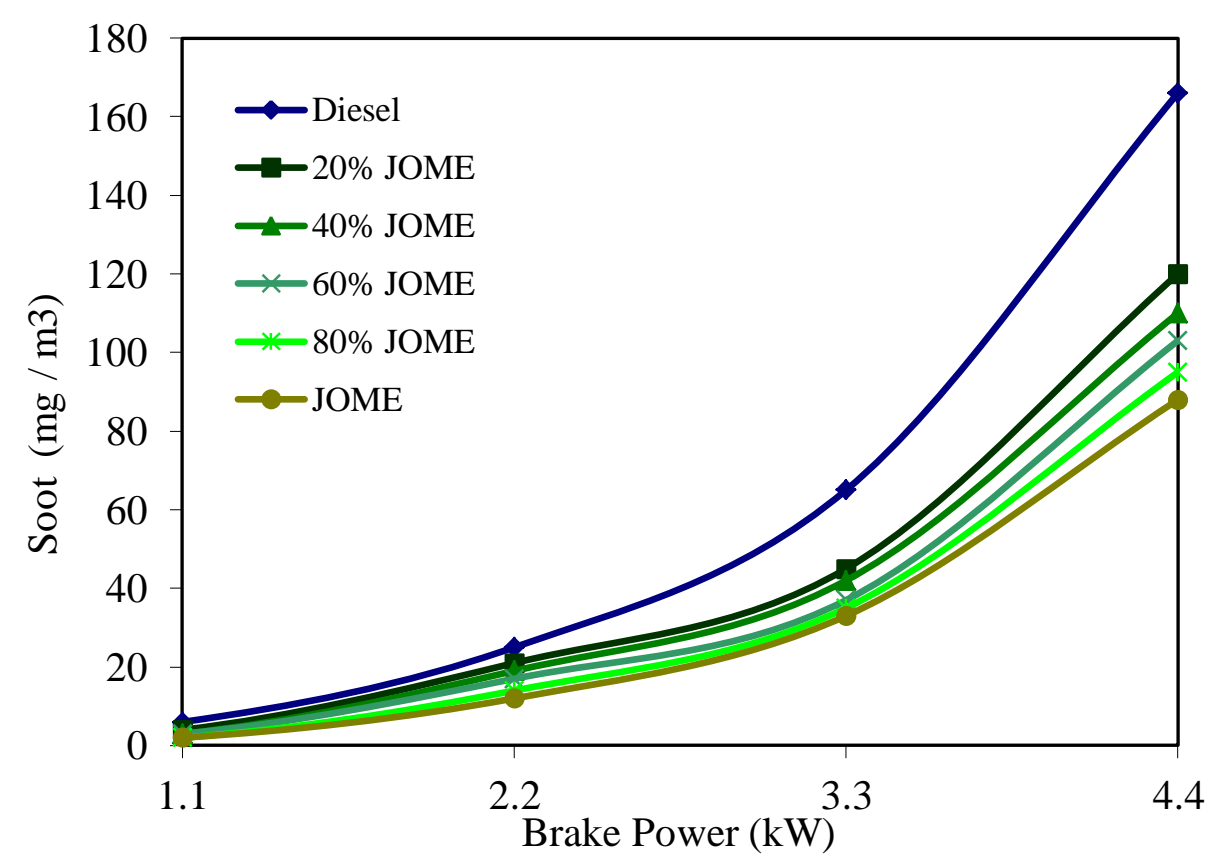

Figure 8. Variation of Soot with Brake power

AVL 415 Variable Sampling Smoke meter which gives smoke value in FSN and soot concentration in $\mathrm{mg} / \mathrm{m}^{3}$ is used to measure soot in the exhaust. Soot emissions for JOME are significantly reduced compared to diesel due to the following reasons:

- Their higher oxygen content [38].

- They have no aromatic compounds which are considered as soot precursors typically available in petroleum diesel fuel [39][37].

- In addition, oxygen atoms in fatty acid methyl esters bonds to carbon atoms, and therefore prevents carbon atoms from participating in soot growth reactions. The oxidation of fatty acid methyl esters and other oxygenated intermediates also forms $\mathrm{OH}$ radicals, which readily attack unsaturated hydrocarbons and prevent their participation in soot growth reactions. Reduced delay period of methyl esters and their blends advances the start of combustion and increases the residence time of soot particles at elevated temperature and promotes their oxidation [40].

\section{Ignition Delay}

Figures 9 show the variation of ignition delay with brake power in degree crank angle (CAD) for the fuels tested. The ignition delay is usually defined as the period from the start of injection to the start of combustion. Start of injection is given by the engine manufacturer as $23.4^{\circ}$ bTDC (Static injection timing). The start of combustion is the point at which the heat release rate curve starts rising from zero determined from cylinder pressure data. Start of combustion is determined from the AVL indimodule. It is found that marginallylower ignition delays for all methyl ester blends[41] and methyl ester compared to diesel are due to their higher cetane index. At rated power output, the ignition delay of diesel, 20\%, 40\%, 60\%, 80\% JOME in the blends and JOME is determined to be $15.78,14.86,14.62,14.45,14.27$ and $13.9^{\circ} \mathrm{CA}$ respectively. The 
ignition delay decreases with increase in percentage of methyl ester in the blend and this is attributable to their higher cetane index compared to diesel[42].

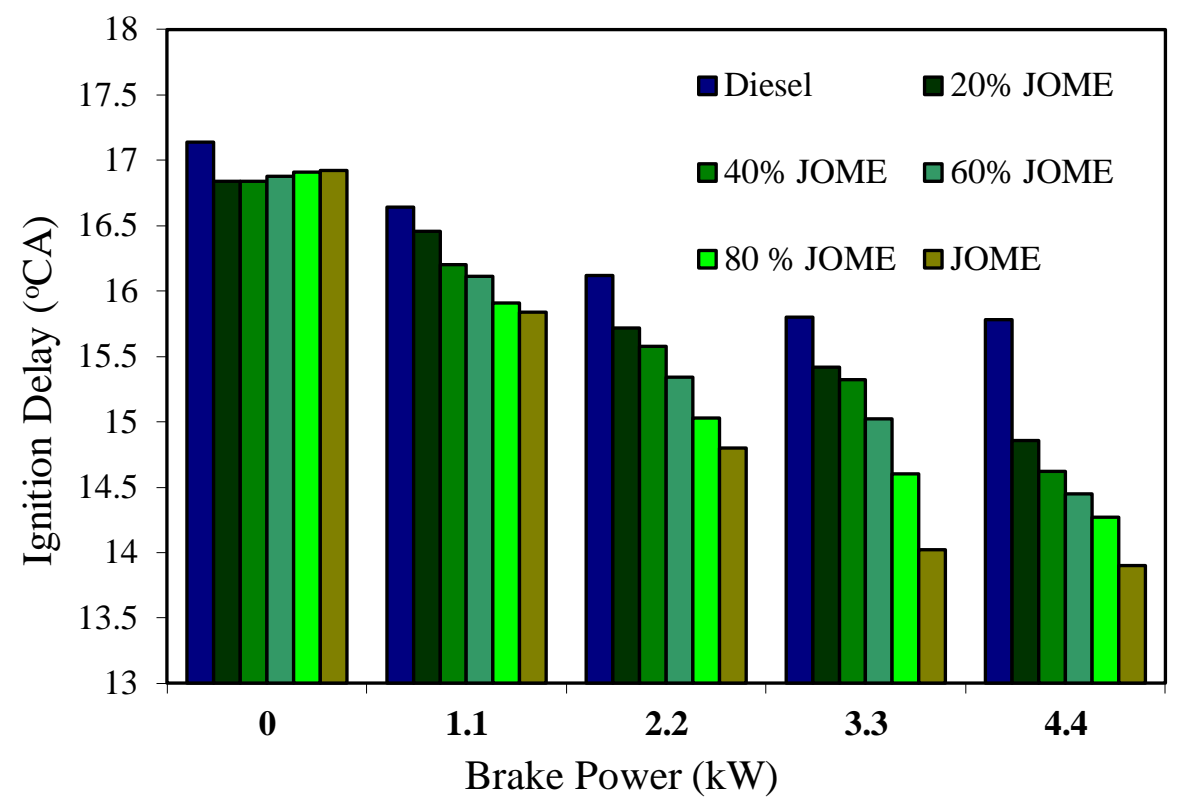

Figure 9. Variation of Ignition Delay with Brake Power

As the amount of biodiesel increases in the blend, the cetane index of the blend increases and this result in a decrease in ignition delay. The ignition delay decreases as the percentage of methyl esters in the blend increases due to the intrinsic oxygen (JOME-10.8\%) present in them. Biodiesel usually includes a small percentage of diglycerides having higher boiling point compared to diesel. However chemical reactions during the injection of biodiesel at high temperature result in the breakdown of high molecular weight esters leading to the formation of gases of low molecular weight. Rapid gasification of these lighter fractions in the fringe of spray spreads out the jet and thus volatile combustion compounds get ignited earlier and reduce the delay period[43].Oleic fatty acid $(40.60 \%)$ and Linoleic fatty acid $(33.40 \%)$ methyl esters present in JOME split into smaller compounds when they enter the combustion chamber resulting in higher spray angles. Hence ignition takes place earlier [44].

\section{Peak Pressure}

It is observed that for both the methyl esters and their blends the peak pressure increases and occurs later compared to diesel as the percentage of methyl esters in the blend increases. Figure 10 show the variation of peak pressure with brake power for diesel, $20 \%, 40 \%, 60 \%, 80 \% \mathrm{JOME}$ in the blend and JOME. The peak pressure is observed to increase with increase in percentage of methyl ester [45][46] and decrease is also observed [47] [48]. The results of the present study show that the peak pressure increases with increase in power output for both the methyl esters and their blends as the oxygen content of methyl esters is higher compared to diesel and the amount of fuel burned increases with increase in power output[49] [50]. 


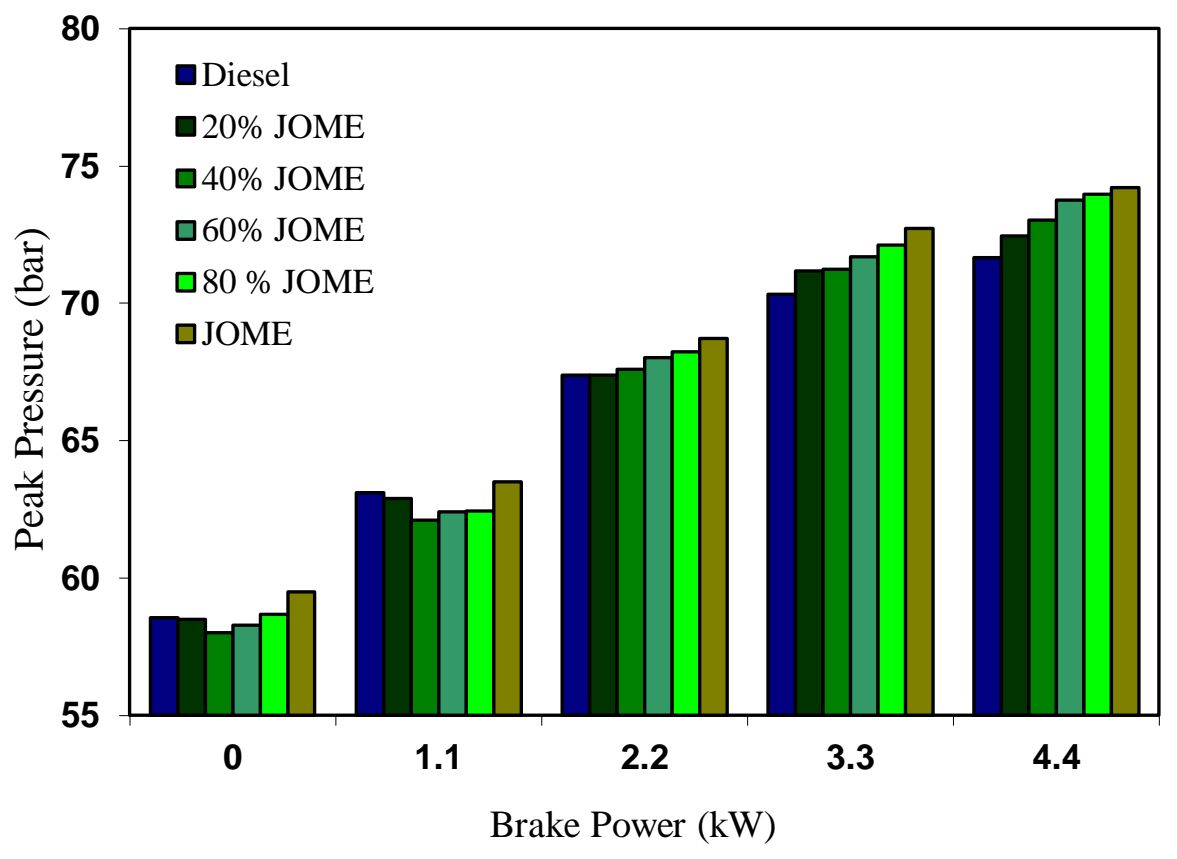

Figure 10. Variation of Peak Pressure with Brake Power

The peak pressure at various power outputs is higher for JOME and its blends compared to diesel. The peak pressure at rated power output is 71.66 bar for diesel, 72.46 bar, 73.02 bar,73.76 bar,73.96 bar and 74.2 bar for 20\%,40\%,60\%,80\% JOME in the blend andJOME respectively.The brake thermal efficiency of $20 \%$ JOME is marginally lower than that of diesel. It can be observed that $\mathrm{CO}, \mathrm{HC}$ and soot emissions are lower while $\mathrm{NO}_{\mathrm{x}}$ emissions are higher for $20 \%$ methyl ester blends compared to diesel as shown in Figure 11. An optimum percentage of methyl esters in the blend are necessary as simultaneous reduction of soot and $\mathrm{NO}_{\mathrm{x}}$ is desirable. The variation of soot and $\mathrm{NO}_{\mathrm{x}}$ values normalized with respect to baseline diesel operation at rated power output for various percentages of JOME is shown in Figures 12. 19\% JOME are observed to be optimum considering both $\mathrm{NO}_{\mathrm{x}}$ and soot emissions. The cost of operation per hour at rated power output, various emissions and brake thermal efficiency at rated power output are given in Table 5.

The JOME are procured in the open market at Rs. 90/-(\$1.5) per liter when compared to Diesel at Rs.54/- (\$0.9) per liter. The cost of methyl esters is likely to come down in the near future with mass production whereas the cost of diesel fuel will increase continuously. From the present experimental results, it can be concluded that $20 \%$ JOME can be successfully used in existing diesel engines without any modifications. 


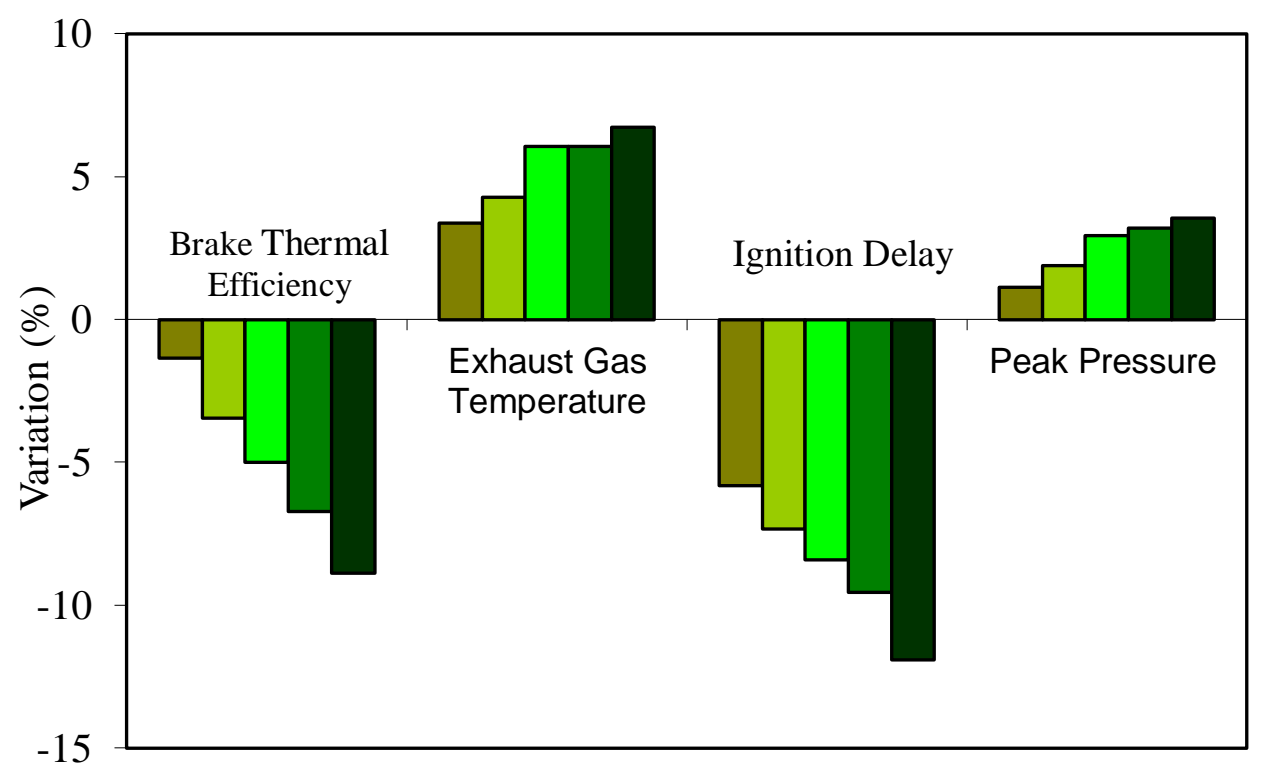

(a)

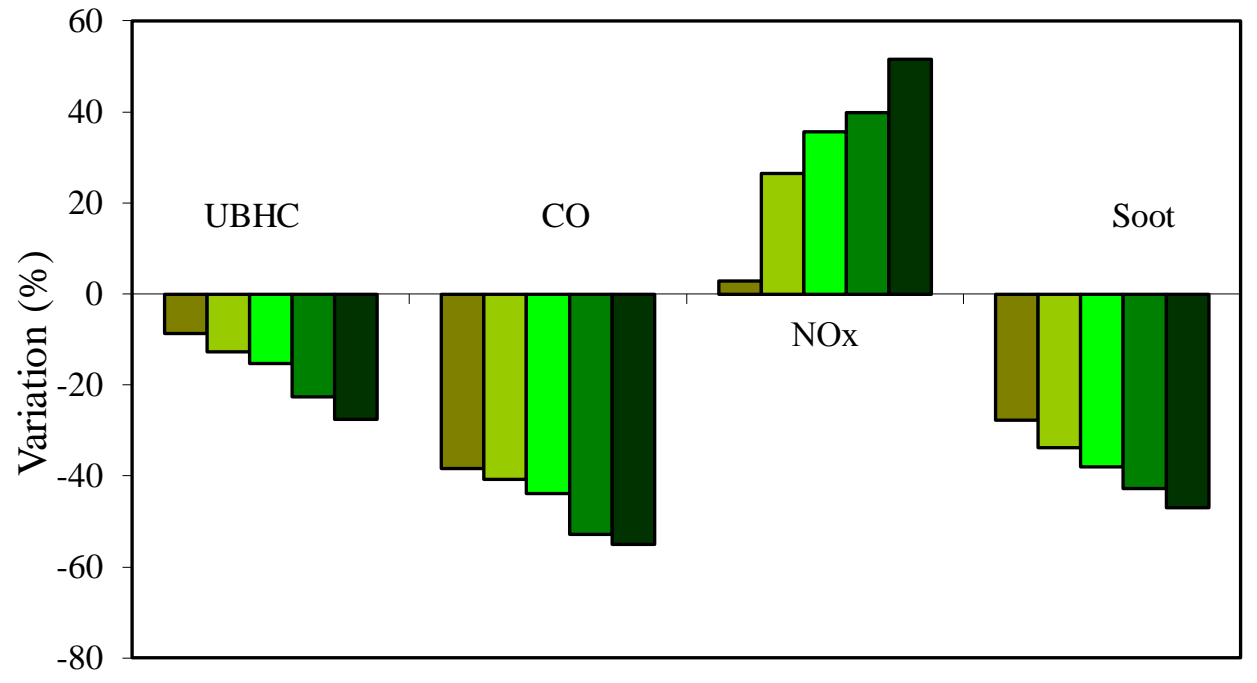

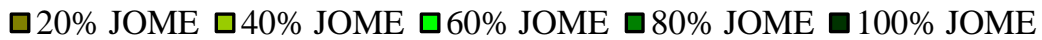

(b)

Figure 11.Comparison of JOME and its Blends with Diesel at Rated Power Output (a) Percentage Variation of Performance and Combustion Parameters (b) Percentage Variation of Emissions 


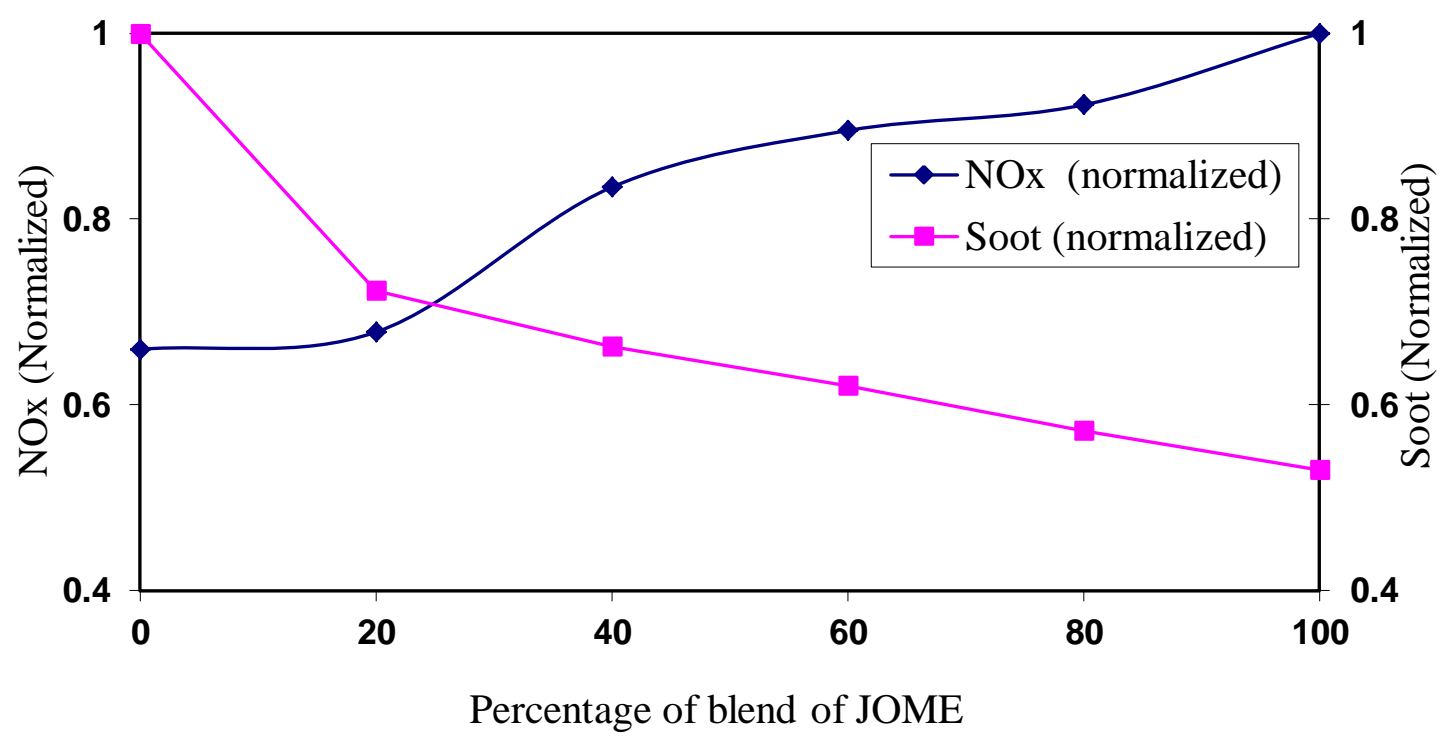

Figure 12.Tradeoff between Oxides of Nitrogen and Soot Emissions for VariousPercentage of JOME in Blend

Table 5. Comparison of 20\% JOME and Diesel Fuel at Rated Power

\begin{tabular}{lccc}
\hline \multicolumn{1}{c}{ Parameters } & Unit & Diesel & 20\% JOME \\
\hline Carbon Monoxide $(\mathrm{CO})$ & $\mathrm{g} / \mathrm{kW} \mathrm{h}$ & 16.75 & 10.33 \\
Unburnt Hydrocarbon $(\mathrm{UBHC})$ & $\mathrm{g} / \mathrm{kW} \mathrm{h}$ & 0.74 & 0.67 \\
Oxides of Nitrogen $\left(\mathrm{NO}_{\mathrm{x}}\right)$ & $\mathrm{g} / \mathrm{kW} \mathrm{h}$ & 7.25 & 7.46 \\
Soot & $\mathrm{mg} / \mathrm{m}^{3}$ & 166 & 120 \\
Brake Thermal Efficiency & $\%$ & 28.4 & 28.1 \\
Cost Per Litre & $\mathrm{INR}(\$)$ & $54(0.87)$ & $61(0.98)$ \\
Cost Per Hour at Rated Power & $\mathrm{INR}(\$)$ & $83(1.33)$ & $96(1.54)$ \\
Output & & & \\
\hline
\end{tabular}

(1 US dollar $(\$)=$ INR 62)

\section{CONCLUSION}

The engine performance and emission characteristics of JOME and JOME blends were investigated and compared with those of normal diesel fuel. It is seen that the engine can be run without any modification with these fuels. The results of this study are summarized as follows:

1. Brake thermal efficiency of the engine with these fuels is found slightly lower than that of diesel. Brake thermal efficiency decreases marginally as the methyl 
ester in the blend increases. At rated power output $(4.4 \mathrm{~kW})$ the specific energy consumption of various fuels tested varies from $12,661.27 \mathrm{~kJ} / \mathrm{kWh}$ to $13,894.25$ $\mathrm{kJ} / \mathrm{kWh}$ and the brake thermal efficiency varies from $28.43 \%$ to $25.91 \%$.

2. Peak pressure is marginally higher for methyl ester at rated power output. The peak pressure at rated power output is 71.66 bar for diesel, 72.46 bar, 73.02 bar,73.76 bar,73.96 bar and 74.2 bar for 20\%,40\%,60\%,80\% JOME in the blend and JOME respectively.

3. $\mathrm{HC}, \mathrm{CO}$ and soot emissions of these fuels are lower compared to those of dieseland decrease as the percentage of methyl esters in the blend increases. At rated power output $(4.4 \mathrm{~kW})$ the carbon monoxide emissions of various fuels tested varies from $16.75 \mathrm{~g} / \mathrm{kWh}$ to $7.53 \mathrm{~g} / \mathrm{kWh}$ and the unburnt hydrocarbon of various fuels tested varies from $0.7366 \mathrm{~g} / \mathrm{kWh}$ to $0.534 \mathrm{~g} / \mathrm{kWh}$. The soot emissions of various fuels tested varies from $166 \mathrm{mg} / \mathrm{m}^{3}$ to $88 \mathrm{mg} / \mathrm{m}^{3}$.

4. Exhaust gas temperature and NOx are observed to be higher for these fuels compared to diesel and increasing the percentage of methyl ester in the blend increases NOx emission. For diesel, the NOx emissions vary from $15.6 \mathrm{~g} / \mathrm{kWh}$ at $20 \%$ of rated power output to $7.45 \mathrm{~g} / \mathrm{kWh}$ at rated power output. For $20 \%$ JOME, 40\% JOME, 60\% JOME, $80 \mathrm{JOME}$ and JOME the variations are from 15.09 to $7.456 \mathrm{~g} / \mathrm{kWh}, 16.82$ to $9.17 \mathrm{~g} / \mathrm{kWh}, 17.7 \mathrm{~g} / \mathrm{kWh}$ to $9.84 \mathrm{~g} / \mathrm{kWh}, 18.9$ $\mathrm{g} / \mathrm{kWh}$ to $9.84 \mathrm{~g} / \mathrm{kWh}$ and $19.29 \mathrm{~g} / \mathrm{kWh}$ to $10.98 \mathrm{~g} / \mathrm{kWh}$ respectively.

5. JOME have higher viscosity compared to diesel. Hence, better lubricity than diesel fuel which will reduce the need for lubricity additives being added to diesel fuel.

6. JOME can be produced economically in the coastal regions where discarded parts of fish are available cheaply.

\section{REFERENCES}

[1] Fazal MA, Haseeb ASMA, Masjuki HH. Biodiesel feasibility study: An evaluation of material compatibility; Performance; emission and engine durability. Renewable and Sustainable Energy Reviews 2011;15:1314-24.

[2] Leung DYC, Wu X, Leung MKH. A review on biodiesel production using catalyzed transesterification. Applied Energy 2010;87:1083-95.

[3] Mohanamurugan S, Sendilvelan S. Emission and combustion characteristics of different fuels in a HCCI engine. International Journal of Automotive and Mechanical Engineering 2011;3:279-92.

[4] Ma FR, Hanna MA. Biodiesel production: a review. Bioresource Technology 1999;70:1-15.

[5] Helwani Z, Othman MR, Aziz N, Fernando WJN, Kim J. Technologies for production of biodiesel focusing on green catalytic techniques: A review. Fuel Processing Technology 2009;90:1502-14.

[6] Bhaskar, K, Sendilvelan, S, Muthu, V, Aravindraj S. Performance and emission characteristics of compression ignition engine using methyl ester blends of jatropha and fish oil. Journal of Mechanical Engineering and Sciences (JMES) 2016;10:1994-2007.

[7] Meher L, Vidyasagar D, Naik S. Technical aspects of biodiesel production by transesterification - a review. Renewable and Sustainable Energy Reviews 2006; 10:248-68. 
[8] Dorado MP, Ballesteros E, Arnal JM, Gómez J, López FJ. Exhaust emissions from a Diesel engine fueled with transesterified waste olive oil. Fuel 2003;82:1311-5.

[9] Khan SA, Rashmi, Hussain MZ, Prasad S, Banerjee UC. Prospects of biodiesel production from microalgae in India. Renewable and Sustainable Energy Reviews 2009;13:2361-72.

[10] Lin C-Y, Lin H-A. Diesel engine performance and emission characteristics of biodiesel produced by the peroxidation process. Fuel 2006;85:298-305.

[11] Yoon SH, Suh HK, Lee CS. Effect of spray and EGR rate on the combustion and emission characteristics of biodiesel fuel in a compression ignition engine. Energy and Fuels 2009; 23: 1486-93.

[12] Sundar Raj C, Sendilvelan S. Effect of oxygenated hydrocarbon additives on exhaust emissions of a diesel engine. International Journal of Automotive and Mechanical Engineering 2010;2: 144-56.

[13] Valente OS, Da Silva MJ, Pasa VMD, Belchior CRP, Sodr?? JR. Fuel consumption and emissions from a diesel power generator fuelled with castor oil and soybean biodiesel. Fuel 2010;89:3637-42.

[14] Srivastava A, Prasad R. Triglycerides-based diesel fuels. Renewable \& Sustainable Energy Reviews 2000;4:111-33.

[15] Vashist D, Ahmad M. Statistical analysis of diesel engine performance for castor and jatropha biodiesel-blended fuel. International Journal of Automotive and Mechanical Engineering 2014;10:2155-69.

[16] Gerpen J Van. Biodiesel production and fuel quality. Department of Biological and Agricultural Engineering, University of Idaho 2005:1-12.

[17] Bamgboye a I, Hansen a C. Prediction of cetane number of biodiesel fuel from the fatty acid methyl ester (FAME) composition. International Agrophysics 2008;22:21-9.

[18] Knothe G. Dependence of biodiesel fuel properties on the structure of fatty acid alkyl esters. Fuel Processing Technology 2005;86:1059-70.

[19] Jaichandar S, Senthil Kumar P, Annamalai K. Combined effect of injection timing and combustion chamber geometry on the performance of a biodiesel fueled diesel engine. Energy 2012;47:388-94.

[20] Friedl A, Padouvas E, Rotter H, Varmuza K. Prediction of heating values of biomass fuel from elemental composition. Analytica Chimica Acta 2005;544:191-8.

[21] Kumar S, Cho JH, Park J, Moon I. Advances in diesel-alcohol blends and their effects on the performance and emissions of diesel engines. Renewable and Sustainable Energy Reviews 2013;22:46-72.

[22] Han WQ, Yao C De. Research on high cetane and high octane number fuels and the mechanism for their common oxidation and auto-ignition. Fuel 2015;150:2940.

[23] D4737 A. Standard Test Method for Calculated Cetane Index by Four Variable Equation. ASTM International 2010;5:1-5.

[24] Stratiev D, Marinov I, Dinkov R, Shishkova I, Velkov I, Sharafutdinov I, et al. Opportunity to improve diesel-fuel cetane-number prediction from easily available physical properties and application of the least-squares method and artificial neural networks. Energy and Fuels 2015;29:1520-33.

[25] Das P, Subbarao PM V, Subrahmanyam JP. Effect of main injection timing for 
controlling the combustion phasing of a homogeneous charge compression ignition engine using a new dual injection strategy. Energy Conversion and Management 2015;95:248-58.

[26] Kumar MS, Bellettre J, Tazerout M. Investigations on a CI Engine Using Animal Fat and Its Emulsions With Water and Methanol as Fuel. SAE Paper 2005;200501-17.

[27] Gómez-Cuenca F, Gómez-Marín M, Folgueras-Díaz MB. Effects of ethylene glycol ethers on diesel fuel properties and emissions in a diesel engine. Energy Conversion and Management 2011;52:3027-33.

[28] Nabi MN, Rahman MM, Akhter MS. Biodiesel from cotton seed oil and its effect on engine performance and exhaust emissions. Applied Thermal Engineering 2009;29:2265-70.

[29] Lapuerta M, Armas O, Rodriguezfernandez J. Effect of biodiesel fuels on diesel engine emissions. Progress in Energy and Combustion Science 2008;34:198-223.

[30] Kitano T, Nishio J, Kurose R, Komori S. Evaporation and combustion of multicomponent fuel droplets. Fuel 2014;136:219-25.

[31] Vallinayagam R, Vedharaj S, Yang WM, Saravanan CG, Lee PS, Chua KJE, et al. Emission reduction from a diesel engine fueled by pine oil biofuel using SCR and catalytic converter. Atmospheric Environment 2013;80:190-7.

[32] Singh SP, Singh D. Biodiesel production through the use of different sources and characterization of oils and their esters as the substitute of diesel: A review. Renewable and Sustainable Energy Reviews 2010;14:200-16.

[33] Heywood JB. Internal Combustion Engine Fundementals. vol. 21. 1988.

[34] Kathirvelu B, Subramanian S. Performance and emission characteristics of biodiesel blends in a premixed compression ignition engine with exhaust gas recirculation. Environmental Engineering Research 2017;22:294-301.

[35] Menkiel B, Donkerbroek A, Uitz R, Cracknell R, Ganippa L. Combustion and soot processes of diesel and rapeseed methyl ester in an optical diesel engine. Fuel 2014;118:406-15.

[36] Stratakis GA, Stamatelos AM. Thermogravimetric analysis of soot emitted by a modern diesel engine run on catalyst-doped fuel. Combustion and Flame 2003;132:157-69.

[37] P.V.Rao. Experimental Investigations on the Influence of Properties of Jatropha Biodiesel on Performance, Combustion, and Emission Characteristics of a DI-CI Engine. World Academy of Science, Engineering and Technology 2011;5:62942.

[38] Sahoo PK, Das LM. Combustion analysis of Jatropha, Karanja and Polanga based biodiesel as fuel in a diesel engine. Fuel 2009;88:994-9.

[39] Wang WG, Lyons DW, Clark NN, Gautam M, Norton PM. Emissions from nine heavy trucks fueled by diesel and biodiesel blend without engine modification. Environmental Science and Technology 2000;34:933-9.

[40] Cardone M, Prati MV, Rocco V, Seggiani M, Senatore A, Vitolo S. Brassica carinata as an alternative oil crop for the production of biodiesel in Italy: Engine performance and regulated and unregulated exhaust emissions. Environmental Science and Technology 2002;36:4656-62.

[41] El-Kasaby M, Nemit-Allah MA. Experimental investigations of ignition delay period and performance of a diesel engine operated with Jatropha oil biodiesel. Alexandria Engineering Journal 2013;52:141-9. 
[42] Saravanan S, Nagarajan G, Narayana Rao GL. Feasibility analysis of crude rice bran oil methyl ester blend as a stationary and automotive diesel engine fuel. Energy for Sustainable Development 2009;13:52-5.

[43] Buyukkaya E. Effects of biodiesel on a di diesel engine performance, emission and combustion characteristics. Fuel 2010;89:3099-105.

[44] Bari S, Saad I. Effect of guide vane height on the performance and emissions of a compression ignition (CI) engine run with biodiesel through simulation and experiment. Applied Energy 2014;136:431-44.

[45] Scholl KW, Sorenson SC. Combustion of soybean oil methyl ester in a direct injection diesel engine. SAE Special Publications 1993:211-23.

[46] Agarwal AK, Dhar A. Comparative Performance, Emission, and Combustion Characteristics of Rice-Bran Oil and Its Biodiesel in a Transportation Diesel Engine. Journal of Engineering for Gas Turbines and Power 2010;132:64503.

[47] Suryawanshi JG, Deshpande N V. Experimental investigations on a jatropha oil methyl ester fuelled diesel engine. Proceedings of the Spring Technical Conference of the ASME Internal Combustion Engine Division 2005:253-60.

[48] Kathirvelu B, Subramanian S, Govindan N, Santhanam S. Emission characteristics of biodiesel obtained from Jatropha seeds and fish wastes in a diesel engine. Sustainable Environment Research 2017;27:283-90.

[49] Baiseitov DA, Tulepov MI, Tursynbek S, Sassykova LR, Nazhipkyzy M., Gabdrashova SE, Kazakov YV, Pustovalov IO, Abdrakova FY, Mansurov ZA, Dalton AB. Processing of the bottomhole zones of oil wells with use of the carbon nanomaterials. Rasayan Journal of Chemistry 2017; 10: 344-8.

[50] Baiseitov D, Tulepov M, Sassykova L, Gabdrashova S, Kudaibergenov K, Mansurov Z. Physicomechanical properties of petrosorbents of the phytogenesis. Revue Roumaine de Chimie 2017; 62: 249-53. 